

\section{Sumário}

EDITORIAL

Bruno Amaral Machado, Camilla de Magalhães Gomes e Soraia Mendes

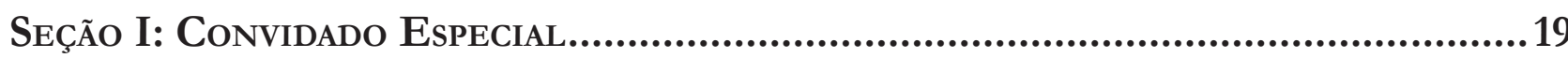

Autonomia Pessoal, Destino, julgamentos e instituições no Brasil: Notas Sobre uma PERGUNTA E ALGUMAS RESPOSTAS

Luiz Edson Fachin

SEÇÃo 2: Dossiê Temático....................................................................................40

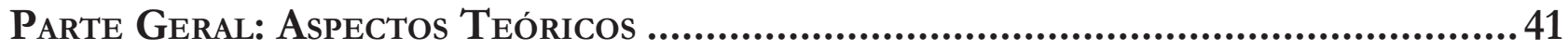

Raça e essencialismo na Teoria Feminista do Direito .......................................................43

Angela P. Harris, Tradução de Camilla de Magalhães Gomes e Ísis Aparecida Conceição

Políticas da morte: Covid-19 E Os Labirintos da Cidade Negra ........................................75

Ana Flauzina e Thula Pires

QUem PARIU AMÉFrica?: TRABALHO DOMÉSTICO, CONSTITUCIONALISMO E MEMÓRIA EM PRETUGUÊS

Juliana Araújo Lopes

O Lixo Vai Falar: Racismo, Sexismo e Invisibilidades do Sujeito Negro nas Narrativas de Direitos Humanos

Ciani Sueli das Neves

DiREITOS HUMANOS, DECOLONIALIDADE E FEMINISMO DECOLONIAL: FERRAMENTAS TEÓRICAS PARA A COMPREENSÃO DE RAÇA E GÊNERO NOS LOCAIS DE SUBALTERNIDADE

Rute Passos, Letícia Rocha Santos e Fran Espinoza

Direito, RAÇA E GÊNERO: ELEMENTOS PARA A CONSTRUÇÃo DE UMA TEORIA FEMINISTA DO DIREITO ADEQUADA AO FEMINISMO NEGRO

Mário Lúcio Garcez Calil e Debora Markman

"NeGras VAdiAs": A CRIMINALIZAÇÃo Do CORPO NEGRO QUE OUSA PROTESTAR.

Soraia da Rosa Mendes e Bruno Amaral Machado

A experiênCia do Abaetê Criolo como aÇão de enfrentamento a desigualdades de GÊNERO E RAÇA: UMA ANÁLISE DE DISCURSO SOBRE INTERSECCIONALIDADE

E FEMINISMO NEGRO

David Oliveira e Thalita Terto Costa 
ENTRE A AUSÊNCIA E O EXCESSO: A ATUAÇÃo DO ESTADO SOBRE CORPOS DISSIDENTES 230 Dayane do Carmo Barretos, Klelia Canabrava Aleixo e Vanessa de Sousa Soares

SILÊNCIOS E MITOS NUMA PERSPECTIVA INTERSECCIONAL: DO CONTROLE INFORMAL DE CORPOS AO CONTROLE PENAL DE MULHERES NEGRAS ......................................................248 Elaine Pimentel e Nathália Wanderley

Ministério Público e domínio Racial: poucas ilhas negras EM UM ARQuipélago nãoNEGRO 267

Saulo Murilo de Oliveira Mattos

Políticas públicas Para a ARTiCulaÇão de GÊNERo E RAÇA: MEIOS PARA GARANTir A REPRESENTATIVIDADE POLÍtiCA E JURÍDiCA DA MULHER NEGRA NO BRASIL 296 Mariana Dionísio de Andrade e Eduardo Régis Girão de Castro Pinto

Parte Específica: Incidências Concretas.......................................................... 317

REIMAGING THE POLICING OF GENDER VIOLENCE: LESSONS FROM WOMEN'S POLICE STATIONS IN Brasil AND ArgENTINA............................................................................................ 319 Kerry Carrington, Melissa Bull, Gisella Lopes Gomes Pinto Ferreira e María Victoria Puyol

NECROBIOPOLIÍtica DE GÊNERo No BRASIL CONTEMPORÂNEO: O FEMINICÍDIO EM TEMPOS DE FASCISMO SOCIAL 340 Maiquel Ângelo Dezordi Wermuth e Joice Graciele Nielsson

ViolÊNCIA CONTRA MULHERES QUILOMBOLAS: UMA REFLEXÃo SOBRE A APLICAÇÃo DE UMA PERSPECTIVA INTERSECCIONAL À LUZ DA IDEIA DE CONTRAPÚBLICOS SUBALTERNOS DELINEADA POR FRASER..... 360 Maria Eugenia Bunchaft, Leonardo Rabelo de Matos Silva e Gustavo Proença da Silva Mendonça

Políticas públicas de PREVEnÇÃo aO Feminicídio E INTERSECCIONALIDAdes . 384 Thiago Pierobom de Ávila, Marcela Novais Medeiros, Cátia Betânia Chagas, Elaine Novaes Vieira, Thais Quezado Soares Magalhães e Andrea Simoni de Zappa Passeto

DiREITO DE VIVER SEM VIOLÊNCIA: PROTEÇÃO E DESAFIOS DOS DIREITOS DAS MULHERES indígenas no Sistema InTERAmericano de Direitos Humanos Julia Natália Araújo Santos e Felipe Rodolfo de Carvalho

ANÁlise de GÊNERo E DE CRUZAMENTOS INTERSECCIONAIS DE UM PROGRAMA PARA AUTORES DE VIOLÊNCIA DOMÉSTICA CONTRA AS MULHERES

Mariana Fernandes Távora, Dália Costa, Camilla de Magalhães Gomes e Adriano Beiras

Controle PENAL dA LOUCURA E DO GÊNERO: REFLEXÕES INTERSECCIONAIS SOBRE MULHERES EgRESSAS DA MEdidA DE SEgurANÇA No Rio DE JANEIRO. .468 Bruna Martins Costa e Luciana Boiteux 
ONDE ESTÃo NOSSOS DIREITOS? O CAMPO FEMINISTA DE GÊNERO BORDADO PELAS MULHERES ATINGIDAS POR BARRAGENS

Tchenna Fernandes Maso e Tchella Fernandes Maso

Os SEGREDOS EPISTÊMICOS DO DIREITO DO TRABALHO.

Flávia Souza Máximo Pereira e Pedro Augusto Gravatá Nicoli

Reforma trabalhista e desigualdade de GÊNERo no Brasil: uMa PERSPECTIVA JuRÍdicA E ECONÔMICA

Natalia Branco Lopes Krawczun, Magno Rogério Gomes e Solange de Cassia Inforzato de Souza

A COLONIALIDADE DO PODER NA PERSPECTIVA DA INTERSECCIONALIDADE DE RAÇA E GÊNERO: ANÁLISE DO CASO DAS EMPREGADAS DOMÉSTICAS NO BRASIL .565

Daphne de Emílio Circunde Vieira Andrade e Maria Cecília Máximo Teodoro

COMPETIÇÃO POLÍTICA E DESIGUALDADES DE GÊNERO NAS ELEIÇÕES PARA ASSEMBLEIAS ESTADUAIS EM 2018

Lígia Fabris Campos, Décio Vieira da Rocha, Leandro Molhano Ribeiro e Vitor Peixoto

DisCrit: os LIMITES DA INTERSECCIONALIDADE PARA PENSAR SOBRE A PESSOA NEGRA COM DEFICIÊNCIA

Philippe Oliveira de Almeida e Luana Adriano Araújo

SeÇão III: Temais GeraIS

La Corte Interamericana de Derechos Humanos. Hermenéutica del derecho al MEDIO AMBIENTE SANO, A LA IDENTIDAD CULTURAL Y A LA CONSULTA, A LA LUZ DE LA SENTENCIA “Lhaka Honhat (nUestra tierra) vs. Argentina” (2020)

Juan Jorge Faundes Peñafiel, Cristobal Carmona Caldera e Pedro Pablo Silva Sánchez

LA RESPUESTA INSTITUCIONAL FRENTE A LA TRATA DE PERSONAS EN EL ESTADO DE CHIHUAHUA.

UN ANÁLISIS DE POLÍTICA PÚBLICA .676 Martha Aurelia Dena Ornelas

Comunidades quilombolas, RaCismo e ideologia no discurso de JAIr Bolsonaro: estudo CRÍTICO DOS DISCURSOS POLÍTICO E JUDICIAL 700 Ricardo de Macedo Menna Barreto e Helena Mascarenhas Ferraz

O Princípio Geral da Boa Administração no Código do Procedimento Administrativo Português. Pistas de inVestigação. 724 Ana Melro 


\title{
Silêncios e mitos numa perspectiva interseccional: do controle informal de corpos ao controle penal de mulheres negras*
}

\author{
Silences and myths in na intersectional \\ perspective: from informal controlof bodies do \\ penal control of black women
}

\author{
Elaine Pimentel ${ }^{* *}$ \\ Nathália Wanderley***
}

\section{Resumo}

O silêncio é uma condição constante na história das mulheres. Silenciadas e controladas pela perspectiva opressora dos sistemas patriarcais, as mulheres foram representadas e descritas por meio de mitos, para atender a identidades fantasiadas, construídas a partir dos olhares dos homens, o que deixou marcas irreparáveis no imaginário coletivo, reduzindo as possibilidades do exercício das liberdades. Entretanto, os processos de opressão que levaram ao silenciamento e à construção de identidades pela força dos mitos, alheios às percepções das próprias mulheres, não atingiu a todas da mesma forma. Condições históricas de desigualdades de raça e de classe levaram a experiências distintas, sobretudo para mulheres negras, que foram estigmatizadas como hiperssexuadas e mais propensas ao desvio e ao cometimento de crimes, tornando-se, assim, mais vulneráveis ao controle penal. O presente texto, amparado em revisão bibliográfica das criminologias críticas e das diversas perspectivas do feminismo negro interseccional, problematiza como o silenciamento histórico e os mitos em torno das mulheres exigem abordagem interseccional, que agregue gênero, raça e classe, além de outras condições de opressão vivenciadas por mulheres, como elementos analíticos indissociáveis, no contexto de suas diferenças. Assim, o texto evidencia, em seus resultados, as razões pelas quais é necessária uma compreensão mais aproximada da realidade histórica de mulheres negras acerca das práticas de controle informal sobre seus corpos, que estão nas bases opressoras e patriarcais do controle formal, exercido por um sistema penal alicerçado no racismo estrutural.

Palavras-chave: Gênero. Silêncio. Mito. Controle de corpos. Interseccionalidade. Controle penal.

Violência em Alagoas (NEVIAL) e Grupo de Pesquisa Educações em Prisões (GPEP), todos registrados no CNPq. É Diretora da Faculdade de Direito da Universidade Federal de Alagoas. E-mail: elaine.pimentel@fda.ufal.br

*** Graduada em Direito pela Faculdade de Direito da Universidade Federal de Alagoas. Mestranda em Direito Público pela mesma instituição. Bolsista CAPES. Integrante dos grupos de pesquisa CARMIM Feminismo Jurídico e Biopolítica e Processo Penal.

E-mail: nmwcavalcante@gmail.com

* Recebido em 30/05/2020

** É doutora em Sociologia pela Universidade ciologia pela Universidade Federal de Alagoas Federal de Alagoas (1999), professora Adjundo Curso de Graduação e Pós-Graduação de Alagoas. É líder dos grupos de pesquisa CARMIM Feminismo Jurídico, Núcleo de Estudos e Políticas Penitenciárias (NEPP) e Vice-líder dos grupos de pesquisa Núcleo de Estudos sobre a 
identities by virtue of the myths, alien to the perceptions of women themselves, did not reach everyone in the same way. Historical conditions of race and class inequality have led to different experiences, especially for black women, who were stigmatized as hypersexual and more prone to deviation and committing crimes, thus becoming more vulnerable to criminal control. The present text, supported by a bibliographic review of critical criminologies and the diverse perspectives of intersectional black feminism, discusses how historical silencing and the myths surrounding women demand an intersectional approach, which adds gender, race and class, in addition to other conditions of oppression experienced by women, as inseparable analytical elements, in the context of their differences. Thus, the text highlights, in its results, the reasons why it is necessary to have a closer understanding of the historical reality of black women about the practices of informal control over their bodies, which are at the oppressive and patriarchal bases of formal control, exercised by a system based on structural racism.

Key words: Gender. Silence. Myth. Control of bodies. Intersectionality. Penal control

\section{Introdução}

Reflexões sobre o feminino exigem sempre um esforço de resgate das condições históricas. O controle sobre as mulheres foi exercido, por muito tempo, de maneira informal no contexto social. Elena Larrauri usa a expressão "controle informal" para se referir a "todas as respostas negativas que provocam certos comportamentos que violam as normas sociais, que não atendem às expectativas comportamentais associadas a um determinado gênero ou função" . Primeiramente, as mulheres eram moldadas pela estrutura familiar, ou mesmo por instituições educacionais e religiosas. E, apenas como último recurso, foram submetidas a controle por mecanismos formais, como o sistema penal e, consequentemente, o cárcere.

Com base no contexto do controle exercido pelo meio social informal, duas formas de opressão e disciplina sobre os corpos das mulheres sobressaíram-se perante as demais: o silêncio e o mito. Ambos, ao logo da história, exerceram forte influência ou até determinaram o lugar que as mulheres poderiam ocupar. Atuaram como mecanismos de controle dos corpos femininos dentro e fora dos lares. O controle exercido sobre os corpos de mulheres primeiro se realiza no âmbito familiar, mas não se encerra ali: atinge a escola e o mercado de trabalho, entre outros âmbitos do meio social, e influencia, diretamente, a forma como se dá o controle penal, no amplo contexto de sistema de justiça criminal, que envolve os mecanismos de segurança pública, as investigações, o processo penal e a execução das penas, sobretudo as privativas de liberdade. Entre o controle de corpos femininos exercido pelos sistemas informais - famílias, escolas, igrejas, mercado de trabalho - e o controle exercido pelos sistemas penais, existem muitas aproximações, pois ambos são marcados pela força opressoras das estruturas patriarcais que tendem a definir lugares e papéis das mulheres na vida social. A partir dessas definições, são geradas expectativas que, quando não atendidas, passam a ser consideradas desvios de comportamento, para os quais são estabelecidas práticas punitivas, informais ou formais.

No entanto, é preciso reconhecer que as mulheres experienciaram opressões distintas ao longo da história. Para além da condição feminina em sociedades estruturadas pelo patriarcado, as desigualdades raciais e sociais, além de outros fatores, somam-se às de gênero, de modo que quaisquer reflexões em torno do controle de corpos de mulheres devem tomar como pressuposto o reconhecimento de que as mulheres ocupam lugares diferentes nas dinâmicas das opressões de gênero, o que exige abordagem interseccional.

Se as mulheres, oprimidas pelo silêncio, não puderam dizer quais os seus lugares na complexidade do

\footnotetext{
"Todas aquellas respuestas negativas que sucitan determinados comportamientos que vulneran normas sociales, que no cumplen las expectativas de comportamiento asociadas a un determinado género o rol LARRAURI, Elena. Control informal: las penas de las mujeres. In: LARRAURI, Elena. Mujeres, derecho penal y criminologia. Madrid: Siglo Veintiuno, 1994. p. 1.
} 
tecido social patriarcal, a história — contada por homens — os ditou. Mas que lugares são esses? A resposta a esse questionamento busca amparo em revisão de literatura sob perspectivas de gênero. Nesse sentido, são importantes os pensamentos de autoras como Heleieth Saffioti (1987-2013), Joan Scott (2019), Michele Perrot (2005), Silvia Federici (2017-2019), Simone de Beauvoir (1970) e Soraia Mendes (2017). Na dimensão interseccional necessária para compreender as opressões distintas vivenciadas por mulheres para além do gênero - notadamente raça e classe - os fundamentos são encontrados nas reflexões de Lélia Gonzales (2011), Ângela Davis (2016), Patrícia Hill Collins (2019), Sueli Carneiro (2019), Juliana Borges (2019), Carla Akotirene (2019) e outras que enfrentaram o tema.

O gênero foi pensado com base na perspectiva de Joan Scott, ou seja, como categoria útil de análise histórica ${ }^{2}$, o que compreende observação não somente da relação entre experiências masculinas e femininas no passado, mas também a ligação entre a história do passado e as práticas históricas atuais. Para Joan Scott, o gênero não só é um elemento constitutivo de relações sociais baseado nas diferenças percebidas entre os sexos, como é a forma primeira de significar as relações de poder ${ }^{3}$. Como, então, o gênero funcionou e funciona no controle de corpos femininos? Como essa categoria dá sentido à atual organização social e os mecanismos de controle informais e formais que culminam com o sistema penal?

É na história das mulheres que estão as chaves para a compreensão da influência das desigualdades de gênero na criação e reprodução dos sistemas de controle de corpos femininos. Ocorre que a história das mulheres é também uma história de silêncios ${ }^{4}$. A historiografia silencia sobre a condição feminina, fazendo-a aparentemente desimportante para as dinâmicas da vida social, dos acontecimentos históricos, das decisões políticas que marcaram épocas. As mulheres não narravam suas próprias vidas e experiências; ao contrário, quando muito, eram ditadas pela perspectiva dos homens. Como consequência do silenciamento, os mitos forjados a partir dos olhares masculinos foram responsáveis por significar as mulheres, estigmatizando-as pela subalternidade imposta em favor do sistema patriarcal.

No entanto, os caminhos percorridos pelas mulheres na história silenciada não foram trilhados igualitariamente. Os silenciamentos, as mistificações, os mecanismos de controle e disciplina tenderam a variar pela influência de opressões somadas às de gênero, como raça e classe. Por isso, exige-se um olhar interseccional, nos termos propostos por Kimberlé Crenshaw ${ }^{5}$, que se fundamenta nos pressupostos do feminismo negro, de modo a romper com a idealização da mulher como sujeito universal, geralmente compreendida como a branca, matriz do feminismo liberal. Os caminhos da interseccionalidade alertam para o fato de que as experiências e vivências das mulheres não são homogêneas, pois conectam elementos de dominação e exploração de mulheres negras a partir das opressões inerentes ao racismo estrutural, denunciando a exclusão, a marginalização e o apagamento de suas histórias. ${ }^{6}$

A interseccionalidade consiste, pois, em aparato dialético importante para a análise dos controles informais e formais exercidos sobre corpos femininos, por meio da imposição de silêncios e da propagação de mitos como verdades universais sobre as mulheres. Juntos, silêncios e mitos reduziram as mulheres, para que coubessem naquilo que o patriarcado determinou como seus lugares, reservando para as mulheres negras uma condição mais acentuada de subalternidade e opressão, o que é refletido não apenas nos diversos mecanismos de controle informal de corpos, mas também naqueles formais, sobretudo no sistema penal.

A questão central sobre a qual se propõe refletir neste texto diz respeito às muitas formas como o silen-

\footnotetext{
2 SCOTT, Joan. Gênero: uma categoria útil para análise histórica. In: HOLANDA, Heloisa Buarque de. (org.). Pensamento feminista: conceitos fundamentais. Rio de Janeiro: Bazar do Tempo, 2019. p. 52. 3

PERROT, Michele. As mulheres on os silêncios da história. Bauru: EDUSC, 2005.

CRENSHAW, Kimberle. Documento para o encontro de especialistas em aspectos da discriminação racial relativos ao gênero. Rev. Estud. Fem. v. 10, n. 1, 2002, Disponível em: https://www.scielo.br/scielo.php?pid=S0104-026X2002000100011\&script=sci_ abstract\&tlng=pt.

6 ARAÚJO, Elita Isabella Morais Dorvillé de. Sobre as mortes das Dandaras: gênero, raça e classe como aportes para pensar uma criminologia feminista e interseccional. Disponível em: http://www.repositorio.ufal.br/handle/riufal/5796. Acesso em: 20 fev. 2020.
} 
ciamento histórico e a mistificação das mulheres foram experienciados a partir de condições de raça e classe social, o que exige da criminologia perspectiva interseccional como caminho analítico necessário para compreender a composição das formas de controle de corpos femininos que estão nas bases do controle penal.

\section{História, silêncios e contole penal: o lugar dos corpos femininos}

Em "As mulheres ou os silêncios da história", Michelle Perrot, logo nas primeiras páginas, denuncia um paradoxo: mulheres-silenciosas. Mas como? Se são sempre vorazes e tagarelas, sob o olhar masculino? Essa visão é também encontrada nos estudos de Lombroso e Ferrero sobre a mulher delinquente, quando, por exemplo, afirmam que, diante da incapacidade das mulheres de guardar segredo, acabavam sendo vítimas de sua fofoca, mesmo quando negavam obstinadamente a culpa. ${ }^{7}$

A história do termo "gossip", atualmente traduzido como "fofoca", é emblemática nesse contexto. Por meio dela, podemos acompanhar dois séculos de ataques contra as mulheres no nascimento da Inglaterra moderna, quando uma expressão que usualmente aludia a uma amiga próxima se transformou em um termo que significava uma conversa fútil, maledicente, isto é, uma conversa que provavelmente semearia a discórdia, o oposto da solidariedade que a amizade entre mulheres implica e produz. Imputar um sentido depreciativo a uma palavra que indicava amizade entre as mulheres ajudou a destruir a sociabilidade feminina que prevaleceu na Idade Média, quando a maioria das atividades executadas pelas mulheres era de natureza coletiva e, ao menos nas classes baixas, as mulheres formavam uma comunidade coesa que era a causa de uma força sem-par na era moderna. ${ }^{8}$

Ao passar adiante os conhecimentos adquiridos, por meio da fala, fossem relativos às curas medicinais, aos problemas amorosos ou à compreensão do comportamento humano, as mulheres tiveram essa espécie de produção de conhecimento rotulada como fofoca. Assim, quando não eram silenciadas violentamente, tinham suas vozes ignoradas e menosprezadas pelo universo masculino, o que representava mais uma forma de degradação. A elas cabia o estereótipo da maldade, da inveja e do poder. ${ }^{9}$

O menosprezo às narrativas femininas ultrapassou as relações personalíssimas e alcançou a historiografia. Para Perrot, "no teatro da memória, as mulheres são uma leve sombra"10, dando ênfase ao déficit documental e o que isso representa. Nesse contexto, ao falar sobre os arquivos do crime, aduz que, apesar de ricos registros para o conhecimento da vida privada, pouco dizem sobre as mulheres, por terem menor peso na criminalidade "não em virtude de uma natureza doce, pacífica e maternal, como pretende Lombroso, mas devido a uma série de práticas que as excluem do campo da vingança ou do afrontamento". ${ }^{11}$ Afirma, então, que "olhar de homens sobre homens, os arquivos públicos calam as mulheres". ${ }^{12}$

Construídas pelo imaginário dos homens, àquelas que não atendiam às expectativas de uma sociedade patriarcal restavam os estigmas da histeria, da loucura ou da delinquência. Quando negras, e se posicionavam, principalmente as retintas, eram aprisionadas em uma imagem de controle ${ }^{13}$ que as apresentava como raivosas, inconvenientes ou sem modos. ${ }^{14}$ Tais imagens, cujos resquícios permanecem até os dias de hoje,

\footnotetext{
LOMBROSO, Cesare; FERRERO, Guglielmo. Criminal Woman, The Prostitute, and The Normal Woman. Durhan: Duke University Press, 2004. p. 191.

8 FEDERICI, Silvia. A história oculta da fofoca: mulheres, caça às bruxas e resistência ao patriarcado. São Paulo: Boitempo, 2019 . p.3. 9 FEDERICI, Silvia. A história oculta da fofoca: mulheres, caça às bruxas e resistência ao patriarcado. São Paulo: Boitempo, 2019. p.13.

10 PERROT, Michele. As mulheres ou os silêncios da bistória. Bauru: EDUSC, 2005. p. 33.

11 PERROT, Michele. As mulheres ou os silêncios da história. Bauru: EDUSC, 2005. p. 35.

12 PERROT, Michele. As mulheres ou os silêncios da história. Bauru: EDUSC, 2005. p. 35.

13 O conceito de imagens de controle pode ser aprofundado em duas obras, a saber: O pensamento feminista negro de Patrícia Hill Collins e Olhares negros: raça e representação de Bell Hooks. Também será melhor abordado adiante.

14 BORGES, Juliana. A construção da "mulher negra criminosa" na sociedade brasileira. In: PIMENTEL, Elaine; DORVILLÉ,
} 
"são traçadas para fazer com que o racismo, o sexismo, a pobreza e outras formas de injustiça social pareçam naturais, normais e inevitáveis na vida cotidiana" ${ }^{\prime 15}$. Tudo isso ditava, para as mulheres brancas e para as negras, os lugares que lhes cabiam.

As mulheres foram, então, representadas em vez de descritas ou contadas. Naturalmente invisibilizadas, foram "privadas da possibilidade de determinar a própria experiência e forçadas a encarar os retratos misóginos ou idealizados que os homens fizeram delas" ${ }^{\text {". }}$. Diversos foram os discursos construídos sobre as mulheres, Com base nos mais diferentes aspectos, sempre a partir da visão masculina, o que passou de geração em geração, resultando em identidades historicamente construídas e aceitas pelo senso comum, delineando padrões de comportamento a serem seguidos. Para uma abundância de discursos sobre as mulheres, ignorou-se, no entanto, o que pensavam a seu próprio respeito ou o que sentiam.

Nesse contexto, de uma identidade imposta e construída socialmente a partir de padrões culturais ${ }^{17}$, vozes como a de Simone de Beauvoir puderam ecoar e fazer entender por que "ninguém nasce mulher: torna-se mulher" ${ }^{18}$, demonstrando que os padrões criados por força da cultura estão enraizados tão profundamente na sociedade, que são tidos como verdadeiros e naturais. No mesmo sentido, Saffioti ${ }^{19}$ afirma:

a identidade social da mulher, assim como a do homem, é construída através da atribuição de distintos papéis, que a sociedade espera ver cumpridos pelas diferentes categorias de sexo. A sociedade delimita, com bastante precisão, os campos em que pode operar a mulher, da mesma forma como escolhe os terrenos em que pode atuar o homem.

Se as mulheres, oprimidas pelo silêncio, não puderam dizer qual o seu lugar, a história — contada por homens - ditou. Em 1869, em "A Sujeição das Mulheres", Stuart Mill, com tom crítico, denunciava o fato de que "todas as mulheres são levadas, desde seus primeiros anos de vida, à crença de que o ideal de seu caráter é exatamente o oposto do ideal do homem; nem vontade própria, nem governo por autocontrole, mas submissão e rendição ao controle de outros" ${ }^{\prime 2}$. Além disso, ainda segundo o autor, às mulheres era passada a ideia de que a docilidade, a submissão e a resignação — ou seja, o silenciamento e a opressão de sua vontade individual —_, faziam parte da atratividade sexual. Essa era uma forma de manter-lhes sob sujeição. ${ }^{21}$

Afinal, subalterna ${ }^{22}$ pode falar? Uma pergunta avassaladora e cética da qual a resposta é: não. Não por ser resultado da mudez, mas porque lhes falta espaço de enunciação. ${ }^{23} \mathrm{O}$ silêncio foi, ao mesmo tempo, disciplina do mundo e dos corpos, uma regra política, social e familiar. As mulheres não podiam falar sobre si mesmas. Também não podia existir queixa, exceto no confessionário, para as católicas.

Foi muito longo o caminho para que as mulheres voltassem a ter voz em uma sociedade profundamente demarcada por opressões de gênero, raça e classe. Da mesma forma, foi grande a demora para que mulheres

Morais Elita. (org.). Mulheres, feminismos e interseccionalidade nas ciências criminais escritos em homenagem a Sueli Carneiro. Maceió: EDUFAL, 2019. p. 99-108.

15 COLLINS, Patrícia Hill. Pensamento feminista negro: conhecimento, consciência e a política do empodera-mento. São Paulo: Boitempo, 2019. p.136.

16 FEDERICI, Silvia. A bistória oculta da fofoca: mulheres, caça às bruxas e resistência ao patriarcado. São Paulo: Boitempo, 2019. p.13.

17 COSTA, Elaine Cristina Pimentel. Amor bandido: As teias afetivas que envolvem a mulher no tráfico de drogas. 2. ed. Maceió: Edufal, 2008.

18 DUTRA Apud BEAUVOIR, Simone de. A criminalidade feminina com relação ao tráfico de drogas, frente à lei 11343/06. Disponível em: http://www.pucrs.br/direito/wp-content/uploads/sites/11/2018/09/thaise_dutra.pdf. Acesso em: 24 fev. 2018.

19 SAFFIOTI, Heleieth. O poder do macho. São Paulo: Moderna, 1987.

20 MILL, John Stuart. Sobre a Liberdade e A sujeição das mulheres. Tradução de Paulo Geiger. Penguin/ Companhia das Letras, 2017. p.87.

21 MILL, John Stuart. Sobre a Liberdade e A sujeição das mulheres. Tradução de Paulo Geiger. Penguin/ Companhia das Letras, 2017. p.87.

22 Aqui entendido através do conceito trabalhado por Spivak e citado por Karina Bidaseca, que compreende aqueles que estão em uma posição de identidade que os coloca à margem da base de ação política, o que inclui a mulher.

23 BIDASECA, Karina. Mujeres blancas buscando salvar a Mujeres color café: desigualdad, colonialismo jurídico y feminismo postcolonial. Andamios, v. 8, n. 17, p. 6189, set./dez. 2011. 
adentrassem no campo da ciência, tanto como objeto de estudo, quanto na qualidade de produtoras de conhecimento. Por muito tempo, as mulheres foram reduzidas às identidades de filhas, irmãs, esposas, viúvas e mães, figuras que tendem a absorver todas as outras. O sentimento maternal, inclusive, foi traço fundamental de análise criminológica, ao longo dos séculos. Com a Revolução Francesa do séc. XVIII, período no qual nenhuma mulher gozava de igualdade política, as mulheres chegaram a tomar as ruas como insurgentes, mas logo foram recolhidas ao espaço doméstico ${ }^{24}$, lugar de opressão, confinamento, silenciamento e, muitas vezes, violência. Nos quartos, locus propícios para o controle de corpos femininos, havia escrivaninhas, diários e histórias não contadas. Nesse contexto, o discurso jurídico era alimentado não somente pelo discurso moral, mas pelos saberes da medicina, que fundamentavam o receio de que as mulheres se tornassem incontroláveis.

Soraia Mendes afirma que a história não deve se limitar a uma descrição do passado, mas constituir esforço para compreensão da vida no agora, evitando-se a repetição daquilo que desumaniza e impede uma vida em plenitude. É sob essa perspectiva que a história da relação ao controle de corpo das mulheres e sua relação com o poder punitivo se revela não apenas como mera referência ao passado, mas como possibilidade de provocar reflexões e repensar presente e futuro. Na história se encontram, portanto, as chaves para desnudar a construção dos exercícios de poder sobre as mulheres, sejam informais ou formais. ${ }^{25}$

Ressalte-se, porém, que, para compreender os mecanismos de controle de corpos exercido sobre mulheres, é indispensável a ruptura com a ideia de que a história é linear e, também, a percepção de que qualquer reconstrução histórica é sempre arbitrária, inclusive quando o objeto de investigação denota estabilidade. ${ }^{26}$ Não cabe, por isso, generalizações de postulados, sem que antes se atente para uma perspectiva histórica e transcultural que considere não somente os dados coletados a partir do séc. XX. Não se pode ignorar as mudanças ocorridas em um espaço de tempo que antecede o advento do capital e o mercantilismo europeu, em primeiro lugar, e mais tarde com a colonização e imperialismo ${ }^{27}$. Em todo esse percurso históricos, as mulheres estavam inseridas nas dinâmicas da vida social, mas foram invisizibilizadas e silenciadas nos registros historiográficos oficiais, sobretudo as mulheres negras, objetificadas pelas desigualdades de raça e classe.

Em qualquer lugar da África que se procure, por exemplo, é possível encontrar dados etno-históricos ${ }^{28}$ atestando que a autoridade já foi compartilhada por mulheres, perdida ao longo da história. Eleanor Leacock alerta, no entanto, que este não é mais um argumento que convalida o matriarcado como um estágio de evolução social, mas que se trata da natureza do processo de tomada de decisão em sociedades anteriores à existência de classes. ${ }^{29}$

$\mathrm{Na}$ alta Idade Média, mulheres participavam de movimentos heréticos e ingressavam em ordens reconhecidas, de modo que a postura religiosa delas era bastante relevante. Algumas, inclusive, eram atuantes na esfera pública, intervindo na economia, na política e na família, o que implicava trabalho no campo e produção de mercadorias. Durante o séc. V ao X, há registros de mulheres integrando o clérigo e monges com elevados níveis educacionais, para o período em questão. Uma perseguição ao gênero e sua repressão irá desenvolver-se mais tarde, séculos à frente, especialmente a partir do séc. XIII, quando aos homens foi dado o poder e o saber para proclamar a fé, além do discurso médico. ${ }^{30}$

24 MENDES, Soraia da Rosa. Criminologia Feminista: Novos paradigmas. São Paulo: Saraiva, 2017. p. 31.

25 MENDES, Soraia da Rosa. Criminologia Feminista: Novos paradigmas. São Paulo: Saraiva, 2017. p.115.

26 CARVALHO, Salo de. A política criminal de drogas no Brasil: estudo criminológico e dogmático da Lei 11.343/06. 8. ed. rev. e atual. São Paulo: Saraiva, 2016. p. 45.

27 LEACOCK, Eleanor Burke. Mitos da dominação masculina: Uma coletânea de artigos sobre as mulheres numa perspectiva transcultural. São Paulo: Instituto Lukács, 2019. p.53.

28 Para consultar exemplos de relatos contrastantes sobre os papéis desempenhados por mulheres em diferentes sociedades e partes do globo, consultar a obra da antropóloga Eleanor Leacock: Mitos da dominação masculina: Uma coletânea de artigos sobre as mulheres numa perspectiva transcultural.

29 LEACOCK, Eleanor Burke. Mitos da dominação masculina: Uma coletânea de artigos sobre as mulheres numa perspectiva transcultural. São Paulo: Instituto Lukács, 2019. p.56.

30 CHERniCHARO, Luciana Peluzio. Sobre Mulheres e Prisões: Seletividade de Gênero e Crime de Tráfico de Drogas no Brasil. 
Segundo Eleanor Leacock, "há quase uma espécie de racismo embutido na premissa de que as culturas dos povos de terceiro mundo permaneceram virtualmente estáticas até que fossem destruídas pela proliferação do industrialismo urbano" "31. A antropóloga destaca, ainda, que uma das mudanças mais consistentes e largamente documentadas durante esse período colonial foi o declínio do status das mulheres em relação aos homens, por causas, em parte, indiretas. Afirma, então:

nesse sentido, a introdução do trabalho remunerado para os homens e o comércio de mercadorias básicas aceleraram processos de fragmentação de coletivos tribais em unidades familiares individuais, em que mulheres e crianças passavam a depender unicamente de um único homem. Esse processo foi reforçado pela outorga aos homens de qualquer tipo de autoridade pública e do direito legal de posse $[\ldots]]^{32}$

O que se quer dizer, com esse relato histórico, é que a naturalização da posição subalternizada das mulheres, que situou os homens como dominantes e detentores de autoridade sobre elas, ignora não só a história mundial, como transmuta a totalidade das estruturas tribais e, portanto, culturais, de tomadas de decisões.

No percurso histórico, a baixa Idade Média revela-se um período paradigmático, no qual as mulheres foram descritas, classificadas e custodiadas de todas as formas. Ao final do séc. XV e início do XVI, a posição social das mulheres começa a ser mais sistematicamente deteriorada. Instituiu-se o que se pode descrever como uma verdadeira guerra contra as mulheres, especialmente, àquelas que pertenciam a classes mais baixas. As acusações por bruxaria e agressões contra esposas "rabugentas" e "dominadoras" eram reflexo do cenário de opressão que se estabelecia. Nesse momento histórico pode-se ressaltar o Malleus Maleficarum ou Martelo das Feiticeiras, uma espécie de manual dos inquisidores que, embora antecedido por outros escritos, foi aquele que se destacou por estabelecer uma relação direta entre a feitiçaria e as mulheres, oferecendo substrato jurídico para os primeiros processos coletivos contra feiticeiras. ${ }^{33}$

A partir dele que se firmou uma relação de crenças na propensão feminina ao delito, por serem supostamente mais fracas na mente e no corpo, o que levantou afirmações quanto à perversidade, malícia e pouca fé das mulheres. O poder punitivo é consubstanciado de modo a reforçar seu poder burocrático e reprimir a dissidência das mulheres. Com isso, tem-se a legitimação de suas agências selecionadoras. Não é unânime entre aqueles e aquelas que estudam a criminologia o momento histórico do seu surgimento, mas Zaffaroni ${ }^{34}$ toma o Malleus Maleficarum como o primeiro discurso criminológico. ${ }^{35}$

Em La Donna Delinquente, Lombro e Ferrero, ao estudarem a mulher criminosa, referendados pela cientificidade positivista, conseguiram, no campo penal, reunir os discursos médico, jurídico e moral (religioso). $\mathrm{Na}$ teoria do atavismo, as mulheres seriam fisiologicamente inertes e passivas e a prostituta veio a se tornar o melhor exemplo de delinquente feminina. ${ }^{36}$

Tem-se, então, entre o fim do séc. XIX e início do XX, o paradigma etiológico, que influenciou os estudos criminais sobre homens e mulheres. Essa nova abordagem individualizava os sinais antropológicos da criminalidade e observava indivíduos que continham tais sinais dentro do universo social, especialmente os que integrassem o cárcere ou manicômios judiciais. A criminologia passa a ter a função de analisar as causas do crime (etiologia) e dos fatores que determinavam o comportamento criminal, o que recaía de maneira

2014. 160f. Dissertação (Mestrado em Direito) - Centro de Ciências Jurídicas e Econômicas, Faculdade de Direito Universidade Federal do Rio de Janeiro, Rio de Janeiro, 2014. p.24.

31 LEACOCK, Eleanor Burke. Mitos da dominação masculina: Uma coletânea de artigos sobre as mulheres numa perspectiva transcultural. São Paulo: Instituto Lukács, 2019. p. 53.

32 LEACOCK, Eleanor Burke. Mitos da dominação masculina: Uma coletânea de artigos sobre as mulheres numa perspectiva transcultural. São Paulo: Instituto Lukács, 2019. p.53.

33 MENDES, Soraia da Rosa. Criminologia Feminista: Novos paradigmas. São Paulo: Saraiva, 2017. p. 21.

34 Segundo o autor, ao longo da história a ideologia da punição afastou-se do biologicismo e buscou construir a inferioridade a partir da moral. Porém, com relação as mulheres, construiu-se assim como ainda se constrói uma inferioridade biológica e moral. [Discurso feminista e poder punitivo. PIERANGELI, José Henrique (coord.). Direito Criminal. Belo Horizonte: Del Rey, 2001. p.49-84.

35 MENDES, Soraia da Rosa. Criminologia Feminista: Novos paradigmas. São Paulo: Saraiva, 2017. p.20.

36 MENDES, Soraia da Rosa. Criminologia Feminista: Novos paradigmas. São Paulo: Saraiva, 2017. p.43-45. 
muito peculiar sobre as mulheres acusadas ou já condenadas por crimes. ${ }^{37}$ Essa fase é conhecida como a era lombrosiana, que associava beleza e prostituição para medir a periculosidade das mulheres.

Soraia Mendes e Vera Malaguti concordam que o positivismo teria atualizado historicamente a programação criminalizante da inquisição moderna. ${ }^{38}$ Todavia, apenas de forma aparente, "o método patologizante abandona a fé em Deus e se agarra no cientificismo, espraiando-se na sociologia, na psicologia, na pedagogia, na antropologia, nas disciplinas em geral" 39 .

Ao longo dos séculos XVI e XVII, as mulheres perderam espaço em todas as áreas da vida social. A presença em público passou a ser malvista, e as mulheres foram orientadas a não sentar em frente as suas casas, nem ficar perto das janelas, ou mesmo reunirem-se com suas amigas. Inclusive, não deveriam visitar os pais com frequência depois do casamento. Foram acusadas de gozarem de pouca razoabilidade, de vaidade e de selvageria, e a voz feminina passou a ser especialmente culpável, um instrumento de insubordinação, por isso deveriam ser controladas. A principal vilã passou a ser a esposa desobediente que, ao lado da desbocada, da bruxa e da puta, eram alvos favoritos dos dramaturgos, escritores populares e moralistas. ${ }^{40} \mathrm{~A}$ visão do que era ou deveria ser a mulher era disseminada, e os mitos cercavam e construíam uma identidade feminina aceita pela sociedade.

É nesse contexto que novas leis e formas de tortura eram destinadas a controlar e oprimir o comportamento das mulheres. Nessa época, era da razão, na Europa eram colocadas focinheiras naquelas acusadas de serem desbocadas que, como cães eram exibidas nas ruas. ${ }^{41} \mathrm{Na}$ Inglaterra, mesmo um século depois, ainda havia relatos de mulheres punidas com uma mordaça ${ }^{42}$, o que se assemelhava a um aro e envolvia-lhes a cabeça com uma corrente presa a ele e uma haste de ferro que era introduzida na boca da mulher. ${ }^{43} \mathrm{O}$ silêncio era um dever e uma punição. Além disso, a emergência do controle de corpos femininos justificou a apropriação do trabalho das mulheres pelos homens e até a criminalização do controle sobre a reprodução. ${ }^{44}$

Esse período, que pode ser denominado de caça às bruxas ${ }^{45}$, foi um momento decisivo na vida das mulheres. Muitas delas foram submetidas a práticas punitivas horríveis, deixando marcas no imaginário coletivo e no senso de possibilidades. Aos poucos foi surgindo um novo modelo de feminilidade: a mulher domesticada: esposa ideal, passiva, obediente, casta e de pouquíssimas palavras, sempre ocupada com as tarefas do lar. ${ }^{46}$ Nesse contexto, "a caça às bruxas é elemento histórico marcante enquanto prática misógina de perseguição" 47 . Seu impacto foi tamanho, que, por mais de três séculos, nenhuma mulher restou ilesa aos delírios persecutórios desse tempo. Do Martelo das Feiticeiras até o séc. XIX, a criminologia, salvo referencias esporádicas, não mais se ocupou das mulheres. ${ }^{48}$

\footnotetext{
37 CHERniCHARO, Luciana Peluzio. Sobre Mulheres e Prisões: Seletividade de Gênero e Crime de Tráfico de Drogas no Brasil. 2014. 160f. Dissertação (Mestrado em Direito) - Centro de Ciências Jurídicas e Econômicas, Faculdade de Direito Universidade Federal do Rio de Janeiro, Rio de Janeiro, 2014. p.33.

38 MENDES, Soraia da Rosa. Criminologia Feminista: Novos paradigmas. São Paulo: Saraiva, 2017. p. 50.

39 BATISTA, Vera Malaguti. A nomeação no mal. In: MENEGAT, Mariildo; NERI, Regina (org.). Criminologia e subjetividade. Rio de Janeiro: Lumen Juris, 2005. p. 40-41.

40 FEDERICI, Silvia. Calibã e a bruxa: Mulheres, corpo e acumulação primitiva. São Paulo: Editora Elefante, 2017. p. 199-202.

41 FEDERICI, Silvia. Calibã e a bruxa: Mulheres, corpo e acumulação primitiva. São Paulo: Editora Elefante, 2017. p. 203.

42 Tal instrumento de tortura era, muitas vezes, importado por autoridades para dentro do lar. Embora o amordaçamento de mulheres estivesse associado, majoritariamente, a um desfile público, o instrumento também era preso a uma das paredes da casa, onde a mulher permanecia até que o marido decidisse libertá-la. DAVIS, Ângela. Estarão as prisões obsoletas? 3. ed. Rio de Janeiro: Difel, 2019. p.44-45

43 DAVIS, Ângela. Estarão as prisões obsoletas? 3. ed. Rio de Janeiro: Difel, 2019. p.45.

44 FEDERICI, Silvia. Calibã e a bruxa: Mulheres, corpo e acumulação primitiva. São Paulo: Editora Elefante, 2017. p.203.

45 A identificação das mulheres como bruxas foi uma estratégia largamente difundida para promover o controle das práticas femininas que vigoravam nas sociedades campesinas e que, em certo momento, foram vistas como modos de resistência às determinações de um Estado a favor da economia em expansão.

46 FEDERICI, Silvia. Calibã e a bruxa. Mulheres, corpo e acumulação primitiva. São Paulo: Editora Elefante, 2017. p.205.

47 MENDES, Soraia da Rosa. Criminologia Feminista: Novos paradigmas. São Paulo: Saraiva, 2017. p. 28-29.

48 MENDES, Soraia da Rosa. Criminologia Feminista: Novos paradigmas. São Paulo: Saraiva, 2017. p. 28-29.
} 
Todas essas experiências, porém, foram vivenciadas em contextos históricos, geográficos e políticos distintos. No Brasil, durante a fase colonial, era comum a perseguição de mulheres curandeiras e parteiras, ou seja, daquelas que detinham conhecimento sobre o próprio corpo. Um saber informal que era transmitido de mãe para filha por meio da fala e, muitas vezes, essencial para sobrevivência não só das mulheres, mas também dos costumes femininos, foi alvo de intensa repressão. Ao substituírem a falta de médicos e cirurgiões, elas acabaram na mira da Igreja. ${ }^{49}$ Del Priore traz o exemplo de um processo-crime contra a escrava Maria, por feitiçaria, que apenas livrou-se da condenação diante da ausência de cirurgião:

no processo, o escrivão nota que na vila existia apenas um cirurgião, o qual "por padecer numa enfermidade de um flato epicôndrio, não usava curar enfermos". Por causa da impossibilidade de o cirurgião prestar assistência aos doentes era costume mulheres aplicarem alguns remédios aos enfermos curando com ervas e raízes que suas experiências lhes administram, as quais são toleradas pelas justiças pela penúria e falta de médicos e professores de medicina, aplicando ervas e raízes por ignorarem remédios. $^{50}$

O discurso criminológico surgido tanto na Europa quanto nas colônias se configurou, então, como um discurso de perseguição, controle e repressão às mulheres consideradas perigosas. O patriarcado se revelou a primeira grande privatização do controle social punitivo. por meio do processo de silenciamento, controlou além do corpo, uma transmissão cultural por meio da oralidade feminina. O sexismo fez com que as mulheres fossem queimadas como bruxas na Inquisição, sendo destruídas sob a forma de bibliotecas de oralidade na Europa. Já as africanas, nas Américas, foram impedidas até mesmo de pensar. Impedidas de orar ou praticar seus fundamentos, foram submetidas aos racismos epistêmicos religiosos e depois ao racismo de cor. ${ }^{51}$

Sônia Giacominni, analisando a opressão exercida sobre as mulheres dentro da realidade brasileira, considera ter ocorrido um duplo silêncio. Ao silêncio sobre as mulheres, em geral, tendo em vista que "a história é masculina, somou-se o silêncio sobre as classes exploradas, pois "a história é das classes dominantes". ${ }^{52}$ Sobre a exploração de classe, afirma que muito já foi dito. Já a opressão de gênero, principalmente com base em um recorte de raça, aparece apenas travestido na mitologia sobre a natureza patriarcalista do escravagismo brasileiro. ${ }^{53}$

Se a historiografia também foi campo de silenciamento, pouco se detendo nas relações de gênero — em especial na sua associação com a raça, segundo Sueli Carneiro —, será a ficção, aqui lida como "mito", que, de maneira mais sistemática, se encarregará de estabelecer os atributos definidores do ser mulher e mulher negra em nossa sociedade ${ }^{54}$, de modo a influenciar as práticas punitivas em sociedades patriarcais e misóginas. O silêncio serviu ao controle social das mulheres em geral, e ditou o lugar que deveria ocupar. O mito, por sua vez, assumiu, mais profundamente, o seu papel com relação às mulheres negras. Por essa razão, a construção das identidades, a opressão exercida sobre das mulheres negras e sua relação com o sistema penal é temática que precisa ser compreendida sob uma perspectiva interseccional.

Kimberlé Crenshaw define interseccionalidade como "uma conceituação do problema que busca capturar as consequências estruturais e dinâmicas da interação entre dois ou mais eixos da subordinação" 55 . Isso porque qualquer abordagem interseccional considera os caminhos pelos quais "o racismo, o patriarcalismo, a opressão de classe e outros sistemas discriminatórios criam desigualdades básicas que estruturam as posi-

\footnotetext{
49 CHERNICHARO, Luciana Peluzio. Sobre Mulheres e Prisões: Seletividade de Gênero e Crime de Tráfico de Drogas no Brasil. 2014. 160f. Dissertação (Mestrado em Direito) - Centro de Ciências Jurídicas e Econômicas, Faculdade de Direito Universidade Federal do Rio de Janeiro, Rio de Janeiro, 2014. p.31.

50 PRIORE, Mary Del, (Org.). História das Mulheres no Brasil. 8. ed. São Paulo: Contexto. p.81.

51 AKOTIRENE, Carla. Interseccionalidade. São Paulo: Sueli Carneiro; Pólen, 2019. p.39.

52 GIACOMINI, 1988 apud CARNEIRO, Sueli. Escritos de uma vida. São Paulo: Pólen Livros, 2019. p.154.

53 GIACOMINI, 1988 apud CARNEIRO, Sueli. Escritos de uma vida. São Paulo: Pólen Livros, 2019. p.154.

54 CARNEIRO, Sueli. Escritos de uma vida. São Paulo: Pólen Livros, 2019. p.155.

55 CRENSHAW, Kimberle. Documento para o encontro de especialistas em aspectos da discriminação racial relativos ao gênero. Rev. Estud. Fem. v. 10, n. 1, 2002, Disponível em: https://www.scielo.br/scielo.php?pid=S0104-026X2002000100011\&script=sci_ abstract\&tlng=pt. p. 177.
} 
ções relativas de mulheres, raças, etnias, classes e outras" ${ }^{56}$.

A ideia de interseccionalidade trazida por Crenshaw ampara-se numa severa crítica às tendências teóricas e políticas superinclusivas, nas quais condições de subalternidade que são identificados nas experiências peculiares de grupos de mulheres passam a ser considerados como inerentes a um problema central de gênero, ou seja, contemplados na condição feminina. "O problema dessa abordagem superinclusiva é que a gama total de problemas, simultaneamente produtos da subordinação de raça e de gênero, escapa de análises efetivas $^{57}$. E é nesse sentido que a interseccionalidade aparece como via analítica importante para pensar as condições em que silêncio e mito tornaram-se ferramentas para o exercício do controle de corpos femininos ao longo da história narrada pelos olhares opressores do patriarcado, sustentáculo das práticas punitivas.

\section{Reflexo do mito: a construção e opressão das identidades das mulheres negras por uma perspectiva interseccional}

A psicologia analítica de Carl Gustav Jung, assim como antropólogos(as) e estudiosos(as) da religião, dos quais são exemplos Joseph Campbell e Mircea Eliade, vêm apresentar o mito não como uma fuga da realidade, fantasia ou fabulação primitiva, mas uma realidade viva e uma forma de atribuir sentido ao mundo, aos fatos, às relações humanas. Afirmam que o mito vem satisfazer às necessidades simbólicas e de significado da psique e atuar como campo fértil tanto para o senso comum como para o conhecimento científico, principalmente nas ciências humanas. Inclusive, é possível falar em uma consciência coletiva construída a partir do mito: a consciência mítica, ${ }^{58}$.

Os séculos XV ao XVII foram importantes marcos temporais para entender o processo de silenciamento das mulheres, e a consequente disciplinarização de seu corpo, no contexto da Idade Média, com a caça às bruxas. No século XX, o deslocamento dos eixos das pesquisas na área da psicanálise, das origens das sociedades para a história de vida das pessoas, com seus ajustamentos inadequados e estados patológicos, representou uma transformação na forma de lidar com os episódios da vida humana. ${ }^{59}$

Nessa fase, a teoria freudiana teve grande repercussão com questões ligadas à sexualidade, que afrontavam a moral social, o que contribuiu para manter a mulher envolta em mitos, responsáveis pelas limitações dos papéis sociais a elas atribuídos. ${ }^{60}$ Não se deve confundir, no entanto, o mito com a apreensão de uma significação somente, pois esta é indissociável ao objeto, é revelada à consciência numa experiência viva, ao passo que o mito é uma ideia transcendente que escapa a toda tomada de consciência. ${ }^{61}$

Freud não viveu em um tempo qualquer: o mundo estava em ebulição e a sociedade passava por mudanças significativas. Era a modernidade. Como um retrato de seu tempo, o autor sucumbiu à falocracia que silenciava e sufocava as mulheres. As afirmações que fez sobre as mulheres eram, antes de tudo, aquilo que

\footnotetext{
56 CRENSHAW, Kimberle. Documento para o encontro de especialistas em aspectos da discriminação racial relativos ao gênero. Rev. Estud. Fem. v. 10, n. 1, 2002, Disponível em: https://www.scielo.br/scielo.php?pid=S0104-026X2002000100011\&script=sci_ abstract\&tlng=pt. p. 177.

57 CRENSHAW, Kimberle. Documento para o encontro de especialistas em aspectos da discriminação racial relativos ao gênero. Rev. Estud. Fem. v. 10, n. 1, 2002, Disponível em: https://www.scielo.br/scielo.php?pid=S0104-026X2002000100011\&script=sci_ abstract\&tlng=pt. p. 174.

58 SERBENA, Carlos A. Considerações sobre o inconsciente: Mito, símbolo e arquétipo na Psicologia analítica. Disponível em: http://pepsic.bvsalud.org/scielo.php?script=sci_arttext\&pid=S1809-68672010000100010http://pepsic.bvsalud.org/scielo.php?script=sci_ar ttext\&pid=S1809-68672010000100010. Acesso em: 27 de janeiro de 2020.

59 SAFFIOTI, Heleieth Iara Bongiovani. A Mulher na Sociedade de Classes: mito e realidade. 3. ed. São Paulo: Expressão Popular, 2013. p. 402-403.

60 SAFFIOTI, Heleieth Iara Bongiovani. A Mulher na Sociedade de Classes: mito e realidade. 3. ed. São Paulo: Expressão Popular, 2013. p.403-404.

61 BEAUVOIR, Simone de. O segundo sexo. São Paulo: Difusão Europeia do Livro, 1970. p.301.
} 
se comentava na sociedade da época. ${ }^{62} \mathrm{O}$ que pode ser visto com desconfiança, no entanto, é o fato de ter forçado cientificidade às suas conclusões e, consequentemente, influenciado o pensamento de uma época. Observam-se resquícios de suas ideias até hoje, a exemplo do mito da passividade feminina.

Assimilando o ativo ao viril e o passivo ao feminino (e levando isso às últimas consequências), a psicanálise freudiana legitimou cientificamente o velho mito, promovendo sua ampla aceitação nas sociedades baseadas na ciência e na tecnologia científica. Assim, acabou o mito da passividade feminina por se transformar numa verdadeira profecia autorrealizadora. [...] A mulher se definiu, de fato, como uma criatura passiva [...]. Ela elevou à categoria de verdade suprema aquilo que não passava de uma hipótese científica $\left[\ldots . .{ }^{63}\right.$

Segundo Saffioti, o autor teria tentado encontrar na anatomia explicação para os traços psicológicos da mulher, chegando à mesma conclusão errônea e desfavorável a que os mitos oriundos da biologia haviam levado: a anatomia da mulher imprime seu destino. ${ }^{64}$ Ou seja, nascer mulher significava estar fadada a cumprir/adequar-se ao que uma sociedade patriarcal significou para o termo.

A autora ressalta o mito, dentre as formas de controle social, para o comportamento feminino, afirmando que as mulheres preenchem funções precisas já dentro das sociedades competitivas, nas quais é exercido o controle sobre seus corpos, motivando-as a aderir aos padrões ditados pelo sistema. Não seria exagero afirmar que o estado civil das mulheres condicionava, profundamente, sua participação em outros âmbitos, assim como a classe social a que pertencia e sua raça. Com o labelling approach ${ }^{65}$ surge, na criminologia, um novo paradigma que vem romper com o etiológico. Os comportamentos passam a atender a construção de um discurso que os etiqueta e os elegem como desviantes. A sociedade passa a definir quem é o criminoso e, nessa perspectiva, o controle é seletivo e discriminatório, com a primazia do status sobre o merecimento ${ }^{66}$.

Nesse cenário, há a ideologia de uma superioridade masculina, por muito tempo dominante, patrocinada pelo mito de que seu trabalho é o mais importante, por ser único remunerado, e também segundo a qual eram os homens, apenas, que seriam capazes de manter contato com o mundo exterior. Essa perspectiva influenciou a construção de uma cultura de superioridade masculina e expectativas de obediência feminina. Em troca da segurança econômica fornecida, as mulheres deveriam estar dispostas a cumprir sua parte do contrato: cuidado e sexo. Até hoje, a quebra dessas expectativas, não raramente, leva a situações de violência contra as mulheres. ${ }^{67}$

Então, idealmente, pela força da cultura patriarcal forjada nos mitos, as mulheres devem desenvolver um tipo de personalidade capaz de ajustar-se às funções que, em uma sociedade marcada por opressões de gênero, restrinjam-se ao lar, como esposas e mães, com base na biologia. Assim a mística feminina reduziu muito as possibilidades de atuação das mulheres nas sociedades.

Beauvoir explica os mitos e o pensamento mítico em torno das mulheres:

há diversas espécies de mitos. Este, sublimando um aspecto imutável da condição humana que é o "seccionamento" da humanidade em duas categorias de indivíduos, é um mito estático; projeta em um céu platônico uma realidade apreendida na experiência ou conceitualizada a partir da experiência. Ao fato, ao valor, à significação, à noção, à lei empírica, êle substitui uma idéia transcendente, não temporal, imutável, necessária. Essa idéia escapa a qualquer contestação porquanto se situa além do dado; é

\footnotetext{
62 MOLINA, José Artur. O que Frend dizia sobre as mulheres. 2. ed. São Paulo: Editora Unesp, 2016. p. 16-17.

${ }_{63}$ SAFFIOTI, Heleieth Iara Bongiovani. A Mulher na Sociedade de Classes: mito e realidade. 3. ed. São Paulo: Expressão Popular, 2013. p. 409.

64 SAFFIOTI, Heleieth Iara Bongiovani. A Mulher na Sociedade de Classes: mito e realidade. 3. ed. São Paulo: Expressão Popular, 2013. p.403-404.

65 Os autores não são unânimes quanto à nomenclatura ou à melhor designação desta corrente de pensamento. A depender disso, o labeling approach poderá ser sinônimo de teoria da rotulação social, teoria do etiquetamento, teoria da reação social ou ainda teoria interacionista. MENDES, Soraia da Rosa. Criminologia Feminista: Novos paradigmas. São Paulo: Saraiva, 2017. p.51

${ }_{66}$ MENDES, Soraia da Rosa. Criminologia Feminista: Novos paradigmas. São Paulo: Saraiva, 2017. p. 50-54.

67 LARRAURI, Elena. Control informal: las penas de las mujeres. In: LARRAURI, Elena. Mujeres, derecho penaly criminología. Madrid: Siglo Veintiuno, 1994. p. 4. (Tradução livre).
} 
dotada de uma verdade absoluta. Assim, à existência dispersa, contingente e múltipla das mulheres, o pensamento mítico opõe o Eterno Feminino único e cristalizado; se a definição que se dá desse Eterno Feminino é contrariada pela conduta das mulheres de carne e osso, estas é que estão erradas. Declara-se que as mulheres não são femininas e não que a Feminilidade é uma entidade. (BEAUVOIR, Simone de. O segundo sexo. São Paulo: Difusão Europeia do Livro, 1970. p.299).

Beauvoir afirma que todo mito implica um sujeito e este projeta esperanças e temores em um céu transcendente. Uma vez que as mulheres não puderam se colocar como sujeitos, não houve um mito viril em que se refletissem seus projetos. Não possuíam religião, nem mesmo poesia que lhes pertencesse exclusivamente. Foi através dos sonhos dos homens que sonharam e foram os deuses fabricados por eles que adoraram. ${ }^{68}$ Por muito tempo, as mulheres foram exclusivamente definidas em relação aos homens.

[...] a mulher é, a um tempo, Eva e a Virgem Maria. É um ídolo, uma serva, a fonte da vida, uma força das trevas; é o silêncio elementar da verdade, é artifício, tagarelice e mentira; a que cura e a que enfeita; é a presa do homem e sua perda, é tudo o que êle quer ter, sua negação e sua razão de ser.[...] Isso decorre do fato de que ela não é considerada positivamente, tal qual é para si, mas negativamente, tal qual se apresenta ao homem. Pois, se há outros Outro, ela continua, contudo, sempre definida como Outro. [...] A mulher resume a natureza como Mãe, Esposa, e Idéia. Essas figuras ora se confundem e ora se opõem, e cada uma delas tem dupla face. ${ }^{69}$

Não existe, porém, uma mulher universal e essa construção teórica, filosófica e política não estava presente nos escritos de Beauvoir. Não se pode atribuir a todas, igualmente, características ou comportamentos esperados para o que se definiu ser mulher, pelo olhar dos homens. "Na realidade concreta, as mulheres manifestam-se sob aspectos diversos; mas cada um dos mitos edificados a propósito da mulher pretende resumi-la inteiramente. Cada qual se afirmando único, a consequência é existir uma pluralidade de mitos incompatíveis" "70. A mística feminina não atinge todas as camadas sociais, nem no mesmo grau de intensidade nem do mesmo modo. Se as brancas e pertencentes às classes privilegiadas, em alguma medida, sentiram de maneira mais leve os seus efeitos, as negras e demais que estão à margem sofrem os estigmas do mito com maior rigor. As faces das opressões que daí resultam são experienciadas de formas diversas.

Lélia Gonzales fala da importância do lugar do sujeito no discurso e faz uso das categorias lacanianas de infante e sujeito-suposto-saber, para lançar algumas reflexões sobre aquele que não é sujeito do seu próprio discurso à medida que é falado pelos outros. Foi o que aconteceu com as mulheres negras. A autora aduz que o conceito de infante "se constitui a partir de uma análise da formação psíquica da criança que, ao ser falada pelos adultos na terceira pessoa, é, consequentemente, excluída, ignorada, colocada como ausente, apesar da sua presença"’’1. E acrescenta:

da mesma forma, nós mulheres e não-brancas, fomos "faladas", definidas e classificadas por um sistema ideológico de dominação que nos infantiliza. Ao impormos um lugar inferior no interior da sua hierarquia (apoiadas nas nossas condições biológicas de sexo e raça), suprime nossa humanidade justamente porque nos nega o direito de ser sujeitos não só do nosso próprio discurso, senão da nossa própria história. ${ }^{72}$

A categoria do sujeito-suposto-saber também possui relação com as reflexões aqui apresentadas, uma vez que, ainda segundo a autora, refere-se às identificações imaginárias com determinadas figuras, para as quais se atribui um saber que elas não possuem. São exemplos: a mãe, o pai, o psicanalista, a professora,

\footnotetext{
BEAUVOIR, Simone de. O segundo sexo. São Paulo: Difusão Europeia do Livro, 1970. p.182.

BEAUVOIR, Simone de. O segundo sexo. São Paulo: Difusão Europeia do Livro, 1970. p.183-384.

70 BEAUVOIR, Simone de. O segundo sexo. São Paulo: Difusão Europeia do Livro, 1970. p.300.

71 GONZALES, Lélia. Por um feminismo afro-latino-americano. Cadernos de Formação Política do Círculo Palmarino, n. 1, p.13, 2011. Disponível em: https://edisciplinas.usp.br/pluginfile.php /271077/mod_resource/content/1/Por\%20um\%20feminismo\%20Afro-latino-americano.pdf. Acesso em: 04 jan. 2020.

72 GONZALES, Lélia. Por um feminismo afro-latino-americano. Cadernos de Formação Política do Círculo Palmarino, n. 1, p.13, 2011. Disponível em: https://edisciplinas.usp.br/pluginfile.php /271077/mod_resource/content/1/Por\%20um\%20feminismo\%20Afro-latino-americano.pdf. Acesso em: 04 jan. 2020.
} 
entre outros. "Tal categoria permite compreender os mecanismos psíquicos inconscientes que se explicam na superioridade que o colonizado atribui ao colonizador" "ᄁ3. Isso implica aceitação da identidade atribuída pelo outro, superior, como se verdadeira fosse. O olhar do colonizador passa a ser o olhar por meio do qual o sujeito passa a se enxergar, o que produz marcas inapagáveis e, muitas vezes, insuperáveis.

Ângela Davis ressalta que, embora algumas mulheres negras desfrutassem de alguns duvidosos benefícios da ideologia de feminilidade, que enfatizavam o papel das mulheres como mães protetoras, parceiras e donas de casa amáveis para seus maridos, elas eram praticamente anomalias. Vistas como unidades de trabalho, para os proprietários as escravas poderiam ser desprovidas de gênero. As mulheres escravas eram, antes de qualquer coisa, trabalhadoras em tempo integral. ${ }^{74}$ Aqui, já é possível ver uma mudança nos papéis criados para as mulheres brancas a os destinados às negras, que ainda hoje carregam os mitos das mulheres trabalhadoras, emocionalmente fortes e imbatíveis, como se a elas não pertencessem o cuidado e o descanso, físico e emocional. Até que ponto o reconhecimento desses papéis pode ser encarado como um elogio e não mais uma forma de opressão?

O mito da fragilidade feminina, por exemplo, tão rechaçado pela maioria das mulheres brancas e que, como brilhantemente assevera Sueli Carneiro, justificou historicamente a proteção paternalista dos homens sobre as mulheres, provavelmente nunca será reconhecido para a maior parte das mulheres negras, pois nunca foram tratadas como frágeis. Fazem parte de um contingente que trabalhou muito durante séculos, como escravas nas lavouras ou mesmo nas ruas, como vendedoras, quituteiras, prostitutas. Então, quando se fala em romper com o mito da rainha do lar, de que mulheres se fala? ${ }^{75}$

Enquanto presumia-se que a típica escrava era uma trabalhadora doméstica - cozinheira, arrumadeira ou mammy na casa-grande, estereótipos que pretendem capturar a essência do papel das mulheres negras durante o período de escravidão - , a realidade se opunha ao mito. ${ }^{76} \mathrm{~A}$ maioria delas estava no trabalho braçal, nas lavouras, assim como os homens. Quando exerciam trabalho doméstico, estavam disponíveis aos seus donos também para a violência sexual. Por isso "desde o período da escravidão, a condição de vulnerabilidade das trabalhadoras domésticas tem sustentado muitos dos mitos duradouros sobre a "imoralidade" das mulheres negras. ${ }^{77}$

Ângela Davis chama atenção, ainda, para o fato de o trabalho doméstico ser realizado de modo desproporcional por mulheres negras que, por sua vez, são encaradas como ineptas para outras atividades e têm a promiscuidade ligada às suas imagens. "As aparentes inépcia e promiscuidade são mitos que se confirmam

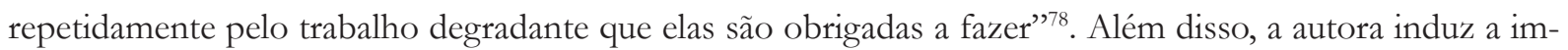
portante reflexão sobre como até os mitos criados para estigmatizar a figura masculina exerceram impacto no modo de enxergar as mulheres negras na sociedade. Nesse sentido, merece destaque o seguinte trecho:

seja de forma inocente ou consciente, suas exposições facilitaram a restauração do desgastado mito do estuprador negro. Sua miopia histórica ainda as impede de compreender que a representação dos homens negros como estupradores reforça o convite aberto do racismo para que os homens brancos se aproveitem sexualmente do corpo das mulheres negras. A imagem fictícia do homem negro como estuprador sempre fortaleceu sua companheira inseparável: a imagem da mulher negra como cronicamente promíscua. Uma vez aceita a noção de que os homens negros trazem em si compulsões sexuais irresistíveis e animalescas, toda a raça é investida de bestialidade. ${ }^{79}$

\footnotetext{
73 GONZALES, Lélia. Por um feminismo afro-latino-americano. Cadernos de Formação Política do Círculo Palmarino, n. 1, p.13, 2011.

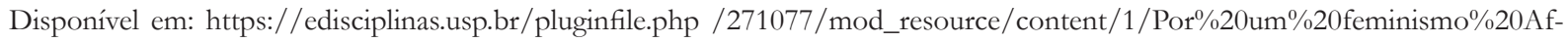
ro-latino-americano.pdf. Acesso em: 04 jan. 2020.

74 DAVIS, Ângela. Mulheres, raça e classe [recurso eletrônico]. São Paulo: Boitempo, 2016. p.24.

75 CARNEIRO, Sueli. Enegrecer o feminismo: a situação da mulher negra na América Latina a partir de uma perspectiva de gênero. In: HOLANDA, Heloísa Buarque de. (org.). Pensamento Feminista: conceitos fundamentais. Rio de Janeiro: Bazar do Tempo, 2019. p.214.

76 DAVIS, Ângela. Mulheres, raça e classe [recurso eletrônico]. São Paulo: Boitempo, 2016. p.24.

77 DAVIS, Ângela. Mulheres, raça e classe [recurso eletrônico]. São Paulo: Boitempo, 2016. p.101.

78 DAVIS, Ângela. Mulheres, raça e classe [recurso eletrônico]. São Paulo: Boitempo, 2016. p.101.

79 DAVIS, Ângela. Mulheres, raça e classe [recurso eletrônico]. São Paulo: Boitempo, 2016. p.101.
} 
A mulheres negras são então, retratadas como exóticas, sensuais, provocativas, com fogo nato, características que chagam a aproximá-las de uma forma animalesca, destinadas exclusivamente ao prazer sexual. ${ }^{80}$ Alek Wek, mulher negra e hoje modelo internacionalmente reconhecida, mas que viveu toda a infância dentro de uma guerra civil no sul do Sudão, quando relata sua história em livro que carrega seu nome, conta como no início da carreira, em Londres, para onde foi na condição de refugiada, sentia-se como um animal. As pessoas a escolhiam para os trabalhos pela sua "exoticidade". Chamava atenção e gerava lucro, já que era tão diferente do padrão europeu. Precisava do dinheiro, então encarou como uma oportunidade de mudar de vida, mas o que vivenciava era bastante doloroso. Conta que muitas vezes só queria responder: “olha, não sou um ser de outro planeta, ouviram bem?!". ${ }^{81}$

Para Ana Gabriela Ferreira, "se a linguagem ao longo de anos, imageticamente, nos afirma esse significante do corpo pronto para a violência, selvagem e não humano, como podemos nos beneficiar de qualquer proteção a garantias voltadas a mulheres?" ${ }^{22}$ Isso porque as vivências de mulheres negras são bem peculiares e exercem impactos outros sobre o sujeito mulher. Da mesma forma "se lidas socialmente, como objetos destinatários de todas as possibilidades de abuso, como seremos alcançadas então por qualquer proposta de limitação deste?" ${ }^{83}$ Essas reflexões mostram caminhos para a compreensão da força dos mitos que estão nas bases das violências reais, simbólicas, estruturais e institucionais exercidas contra mulheres negras ao longo da história, firmando as bases da relação estabelecida entre mulheres negras e o sistema de controle penal.

Sueli Carneiro mostra e faz refletir, no contexto brasileiro, sobre como a sociedade colonial e escravista contribuiu significativamente para a criação do mito de mulheres quentes, atribuído até hoje às negras e mulatas por meio da tradição oral e, muitas vezes, disseminado no meio intelectual pela literatura. Acrescenta que, ao decorrer do séc. XX, o misticismo que envolveu a figura da mulher negra permanece, persistindo a visão de que se destina ao sexo, ao prazer e às relações extraconjugais. Para aquelas desconstituídas desses atrativos, reservava-se a condição de burro de carga. Em suma, segundo ditado popular reproduzido pela autora: "preta pra trabalhar, branca pra casar e mulata pra fornicar". ${ }^{84}$

Cabe aqui adentrar no conceito de imagens de controle, trazido por Patrícia Hill Collins e problematizá-lo, em razão da proximidade com o que neste artigo se definiu como mito. Trata-se da estereotipação da condição de ser uma mulher negra, atribuindo-lhe uma série de imagens negativas, que servem à justificação ideológica da opressão, da exploração e das práticas punitivas no contexto do sistema de justiça criminal e do sistema carcerário. A autora deixa evidente que, enquanto as mulheres brancas das classes mais abastadas e as de classe média emergentes foram encorajadas a aspirar virtudes atreladas ao ideal tradicional de família: piedade, pureza, submissão e domesticidade, como desenvolvido anteriormente, as afro-americanas depararam com um conjunto diferente de imagens de controle, as quais refletem também a realidade brasileira. ${ }^{85}$ Portanto, firmou-se no imaginário social a concepção de certos lugares a serem ocupados pelas mulheres negras, que as tornam vulneráveis diante de estereótipos periféricos, que se somam a condições de classe e, portanto, de marginalidade.

Collins analisa, então, cinco imagens de controle. A “mammy”, serviçal fiel e obediente aos seus empregadores: é a figura criada para "justificar a exploração econômica das escravas domésticas e mantida para

\footnotetext{
30 CARNEIRO, Sueli. Escritos de uma vida. São Paulo: Pólen Livros, 2019. p.155.

81 WEK, Alek. Alek Wek: a refugiada africana que virou top model internacional. São Paulo: Panda Books, 2010. p. 179-193-209.

82 FERREIRA, Ana Gabriela Souza. Atenção para o refrão: que linguagem nos constróis para p direito penal? In: PIMENTEL, Elaine; DORVILLÉ, Morais Elita. (org.). Mulheres, feminismos e interseccionalidade nas ciências criminais escritos em homenagem a Sueli Carneiro. Maceió: EDUFAL, 2019. p.145-150.

83 FERREIRA, Ana Gabriela Souza. Atenção para o refrão: que linguagem nos constróis para p direito penal? In: PIMENTEL, Elaine; DORVILLÉ, Morais Elita. (org.). Mulheres, feminismos e interseccionalidade nas ciências criminais escritos em homenagem a Sueli Carneiro. Maceió: EDUFAL, 2019. pp.145-150.

84 CARNEIRO, Sueli. Escritos de uma vida. São Paulo: Pólen Livros, 2019. p.158.

85 COLLINS, Patrícia Hill. Pensamento feminista negro: conhecimento, consciência e a política do empodera-mento. São Paulo: Boitempo, 2019. p.140.
} 
explicar o confinamento das mulheres negras ao serviço doméstico, [...] representa o padrão normativo usado para avaliar o comportamento das mulheres negras em geral" ${ }^{16}$. É a face que os brancos esperam que as mulheres negras assumam publicamente. Mais recente é a figura da "matriarca", mães solteiras mantedoras da família, desprovidas de feminilidade e excessivamente agressivas, eram supostamente castradoras de seus amantes e maridos. "Enquanto a mammy caracteriza a figura da mãe negra nas famílias brancas, a matriarca simboliza a figura materna nas famílias negras" ${ }^{87}$. A primeira representaria a mãe negra boa, enquanto a segunda a má.

A terceira imagem seria da "mãe dependente do estado". Aqui já é possível enxergar um viés de classe. "É retratada como uma pessoa acomodada, satisfeita com os auxílios concedidos pelo governo, que foge do trabalho e transmite valores negativos para os descendentes" ${ }^{88}$. Dessa forma, acabam estereotipadas racialmente como preguiçosas. No mesmo período surge figura semelhante: a "dama negra". Esta, à primeira vista, parece não simbolizar uma imagem de controle, mas tão somente uma imagem positiva, pois retrata mulheres que concluíram os estudos, trabalharam duro e foram longe. No entanto, retrata mulheres que trabalham duas vezes mais que os outros e são tão exigentes que não teriam tempo para os homens. Como costumam competir com eles e serem bem sucedidas, muitos dos negros acreditam que estariam ocupando cargos que lhes eram reservados. ${ }^{89}$

Quando consideradas simultaneamente, são retratos do ponto de vista de uma tese de matriarcado que tem por finalidade deslegitimar o exercício pleno da cidadania de mulheres negras. A última imagem de controle da condição da mulher negra, trazida pela autora, é a "Jezebel" (prostituta ou hoochie). Representa uma forma desviante de sua sexualidade, já que os esforços para exercer controle sobre elas estão na base de sua opressão. Vistas como sexualmente agressivas, seus comportamentos justificavam, supostamente, os ataques sexuais, o que remete à ideia de que os homens são ativos e as mulheres devem ser passivas. ${ }^{90}$ Esse é o panorama da definição de gênero/raça, instituída pela tradição cultural patriarcal colonial também para as mulheres brasileiras.

Construídas a partir de ficção/mito, as mulheres, em sua ampla diversidade, foram estigmatizadas e hierarquizadas, do ponto de vista do ideal patriarcal. Com o desenvolvimento dos sistemas patriarcais, os mitos tornaram-se estigmas/fardos, que não somente legitimaram a existência de padrões comportamentais, como impuseram, de forma muito mais forte, ao longo da história e até os dias de hoje, mecanismos de controle sobre os corpos das mulheres negras ${ }^{11}$, sobretudo o controle penal.

As mulheres que delinquem, sobretudo as mulheres brancas, sempre foram vistas pelas sociedades como duplamente desviantes, pois ferem não só a lei, mas a expectativa de feminilidade fundada nos mitos, no contexto das opressões patriarcais. ${ }^{92}$ Sempre houve, portanto, a necessidade de controle sobre seus corpos. Com as mulheres negras, a realidade se inverte. Os mitos que construíram a ideia de mulheres hiperssexualizadas ajudaram a construir o mito da mulher naturalmente transgressora e isso povoa o imaginário coletivo historicamente, fortalecendo os sistemas de controle de corpos. Ocorre que, com o tempo, a prisão do lar ou religiosa já não eram suficientes e recorreu-se, então, a outras formas de controle, como o controle penal. É,

\footnotetext{
86 COLLINS, Patrícia Hill. Pensamento feminista negro: conhecimento, consciência e a política do empodera-mento. São Paulo: Boitempo, 2019. p.140-142.

87 COLLINS, Patrícia Hill. Pensamento feminista negro: conhecimento, consciência e a política do empodera-mento. São Paulo: Boitempo, 2019. p.144.

88 COLLINS, Patrícia Hill. Pensamento feminista negro: conhecimento, consciência e a política do empodera-mento. São Paulo: Boitempo, 2019. p.149.

89 COLLINS, Patrícia Hill. Pensamento feminista negro: conhecimento, consciência e a política do empodera-mento. São Paulo: Boitempo, 2019. p.153-154.

90 COLLINS, Patrícia Hill. Pensamento feminista negro: conhecimento, consciência e a política do empodera-mento. São Paulo: Boitempo, 2019. p.153-154.

91 COLLINS, Patrícia Hill. Pensamento feminista negro: conhecimento, consciência e a política do empodera-mento. São Paulo: Boitempo, 2019.p.155-157.

92 CARLEN, Pat; WORRALL, Anne. Analysing Women's Imprisonment. Portland: Willan Publishing, 2004. 'p. 2.
} 
justamente, por meio da percepção das mulheres como duplamente criminosas que o sistema penal assegura sua ordem patriarcal, "seja operando sobre o feminino como vítima - suplicante de "amparo" e incapaz de agir — ou em transgressora, fora da lei masculina e das expectativas de gênero" "’3.

Nesse contexto, as narrativas em torno da criminalidade feminina e a história do aprisionamento de mulheres passou por modificações ao logo do tempo. Se antes seus corpos eram regulados e punidos na esfera doméstica e a prisão era reservada às loucas ou masculinizadas, com o passar das décadas - em uma sociedade ainda marcada pelo patriarcado e noções androcêntricas —, o Estado assumiu o papel de castigador, por meio do controle penal. O exercício do poder punitivo, portanto, diante do delito praticado por uma mulher, vai além da retribuição por violação da norma penal ou dos danos causados a outrem: trata-se, também, de reprimenda por transgressão a normas de gênero ${ }^{94}$ que as situam nos espaços domésticos, com papéis bem delimitados, para as brancas, ou a confirmação das identidades naturalmente transgressoras atribuídas às mulheres negras por força dos mitos.

\section{Considerações finais}

As reflexões aqui apresentadas buscaram evidenciar como, ao longo do tempo, silêncio e mito serviram de instrumentos disciplinares e de controle de corpos femininos, oprimindo e aprisionando as mulheres em identidades construídas a partir das experiências e da perspectiva dos homens, negando peculiaridades inerentes às diferenças raciais e de classe que estão nas bases da ruptura com a perspectiva de mulher universal.

O controle de corpos, de fato, não foi experienciado de maneira igual por todas as mulheres. Se brancas sofreram com o silenciamento que resultou em uma história contada sem considerar o que pensavam sobre si mesmas, as mulheres negras sofreram com maior intensidade, em razão das opressões raciais e de classe, de tal modo que suas histórias não deixaram de ser contadas, mas foram violentamente apagadas das poucas narrativas existentes sobre as mulheres.

Os mitos, por sua vez, revelaram-se instrumentos de controle social informal de corpos femininos e, a depender da raça e classe social a que pertencessem as mulheres, atribuíam caraterísticas e papéis diversos, impondo às mulheres diferentes lugares de subalternidade e opressão em sociedades marcadas pela cultura patriarcal. Enquanto as mulheres brancas tiveram sua imagem vinculada a mitos como a fragilidade feminina e lutaram por um espaço fora do lar, as mulheres negras não puderam estar em casa, cuidando dos seus. Durante a escravidão, foram vistas, apenas, como força de trabalho e violentadas sexualmente, sobretudo por serem consideradas exóticas e sensuais. Por força do mito, essas características permanecem no imaginário social até os dias de hoje, acentuando desigualdades raciais e de classe entre mulheres. Além disso, reproduzem representações em torno dos corpos de mulheres negras como aqueles disponíveis à exploração e à violência e dotados de aptidões para práticas desviantes e crimes, tornando-se as maiores destinatárias dos sistemas de controle penal.

Essas considerações permitem afirmar que uma abordagem do sistema penal exclusivamente amparada em críticas às opressões de gênero não alcançaria a concretude das experiências de mulheres negras, dentro de um contexto social de desigualdade racial e de classe. Por isso, uma leitura interseccional da força do silenciamento das mulheres e dos mitos criados que influenciaram a construção de identidades estereotipadas aproxima-se muito mais das diferentes opressões vivenciadas por mulheres ao longo da história.

Considerar que silêncio e mito operaram sobre a construção das identidades femininas no contexto das desigualdades de gênero, como matrizes opressoras exercidas por homens sobre mulheres em sociedades

93 MARTINS Fernanda; GAUER Ruth M.C. Poder Punitivo e Feminismo: percursos da criminologia feminista no Brasil. Revista Direito e Práxis, Ahead of print, Rio de Janeiro, p. 6, 2019.

94 PIMENTEL, Elaine. As marcas do patriarcado nas prisões femininas brasileiras. Disponível em: https://periodicos.ufpel.edu.br/ojs2/ index.php/revistadireito/article/view/11434/7219. Acesso em: 10 jan. 2020. 
patriarcais, pode ser um ponto de partida para compreender, em parte, o controle de corpos exercido sobre mulheres ao longo da história. No entanto, somente por um olhar interseccional, que agregue raça e classe como elementos indissociáveis das práticas de controle de corpos, inclusive das práticas punitivas, que se alicerça no racismo estrutural, torna-se possível ruptura com os silêncios históricos, abrindo caminhos para uma releitura do passado e do presente que mais se aproxime das experiências próprias das mulheres negras.

\section{Referências}

AKOTIRENE, Carla. Interseccionalidade. São Paulo: Sueli Carneiro; Pólen, 2019.

ARAÚJO, Elita Isabella Morais Dorvillé de. Sobre as mortes das Dandaras: gênero, raça e classe como aportes para pensar uma criminologia feminista e interseccional. Disponível em: http://www.repositorio.ufal.br/ handle/riufal/5796.

BATISTA, Vera Malaguti. A nomeação no mal. In: MENEGAT, Mariildo; NERI, Regina (org.). Criminologia e subjetividade. Rio de Janeiro: Lumen Juris, 2005.

BEAUVOIR, Simone de. O segundo sexo. São Paulo: Difusão Europeia do Livro, 1970.

BIDASECA, Karina. Mujeres blancas buscando salvar a Mujeres color café: desigualdad, colonialismo jurídico y feminismo postcolonial. Andamios, v. 8, n. 17, set./dez. 2011.

BORGES, Juliana. A construção da "mulher negra criminosa" na sociedade brasileira. In: PIMENTEL, Elaine; DORVILLÉ, Morais Elita. (org.). Mulheres, feminismos e interseccionalidade nas ciências criminais escritos em bomenagem a Sueli Carneiro. Maceió: EDUFAL, 2019.

CARLEN, Pat; WORRALL, Anne. Analysing Women's Imprisonment. Portland: Willan Publishing, 2004.

CARNEIRO, Sueli. Enegrecer o feminismo: a situação da mulher negra na América Latina a partir de uma perspectiva de gênero. In: HOLANDA, Heloísa Buarque de. (org.). Pensamento Feminista: conceitos fundamentais. Rio de Janeiro: Bazar do Tempo, 2019.

CARNEIRO, Sueli. Escritos de uma vida. São Paulo: Pólen Livros, 2019.

CARVALHO, Salo de. A política criminal de drogas no Brasil: estudo criminológico e dogmático da Lei 11.343/06. 8. ed. rev. e atual. São Paulo: Saraiva, 2016.

CHERniCHARO, Luciana Peluzio. Sobre Mulheres e Prisões: Seletividade de Gênero e Crime de Tráfico de Drogas no Brasil. 2014. 160f. Dissertação (Mestrado em Direito) - Centro de Ciências Jurídicas e Econômicas, Faculdade de Direito Universidade Federal do Rio de Janeiro, Rio de Janeiro, 2014.

COLLINS, Patrícia Hill. Pensamento feminista negro: conhecimento, consciência e a política do empoderamento. São Paulo: Boitempo, 2019.

COSTA, Elaine Cristina Pimentel. Amor bandido: As teias afetivas que envolvem a mulher no tráfico de drogas. 2. ed. Maceió: Edufal, 2008.

CRENSHAW, Kimberle. Documento para o encontro de especialistas em aspectos da discriminação racial relativos ao gênero. Rev. Estud. Fem. v. 10, n. 1, 2002, Disponível em: https://www.scielo.br/scielo. php?pid=S0104-026X2002000100011\&script=sci_abstract\&tlng=pt.

DAVIS, Ângela. Estarão as prisões obsoletas? 3. ed. Rio de Janeiro: Difel, 2019.

DAVIS, Ângela. Mulheres, raça e classe [recurso eletrônico]. São Paulo: Boitempo, 2016.

DELUMEAU, Jean. História do medo no ocidente: 1300 a 1800. São Paulo: Companhia das Letras, 1989. 
FEDERICI, Silvia. A história oculta da fofoca: mulheres, caça às bruxas e resistência ao patriarcado. São Paulo: Boitempo, 2019.

FEDERICI, Silvia. Calibã e a bruxa. Mulheres, corpo e acumulação primitiva. São Paulo: Editora Elefante, 2017.

FERREIRA, Ana Gabriela Souza. Atenção para o refrão: que linguagem nos constróis para p direito penal? In: PIMENTEL, Elaine; DORVILLÉ, Morais Elita. (org.). Mulheres, feminismos e interseccionalidade nas ciências criminais escritos em homenagem a Sueli Carneiro. Maceió: EDUFAL, 2019.

GONZALES, Lélia. Por um feminismo afro-latino-americano. Cadernos de Formação Política do Círculo Palmarino, n. 1, p.13, 2011. Disponível em: https://edisciplinas.usp.br/pluginfile.php /271077/mod_resource/ content $/ 1 /$ Por $\% 20$ um $\% 20$ feminismo $\% 20$ Afro-latino-americano.pdf.

LARRAURI, Elena. Control informal: las penas de las mujeres. In: LARRAURI, Elena. Mujeres, derecho penal y criminología. Madrid: Siglo Veintiuno, 1994.

LEACOCK, Eleanor Burke. Mitos da dominação masculina: Uma coletânea de artigos sobre as mulheres numa perspectiva transcultural. São Paulo: Instituto Lukács, 2019.

LOMBroso, Cesare; FERRERO, Guglielmo. Criminal Woman, The Prostitute, and The Normal Woman. Durhan: Duke University Press, 2004.

MARTINS Fernanda; GAUER Ruth M. C. Poder Punitivo e Feminismo: percursos da criminologia feminista no Brasil. Revista Direito e Práxis, Ahead of print, Rio de Janeiro, 2019.

MENDES, Soraia da Rosa. Criminologia Feminista: Novos paradigmas. São Paulo: Saraiva, 2017.

MILL, John Stuart. Sobre a Liberdade e A sujeição das mulheres. Tradução de Paulo Geiger. Penguin/ Companhia das Letras, 2017.

MOLINA, José Artur. O que Frend diæia sobre as mulheres. 2. ed. São Paulo: Editora Unesp, 2016.

PERROT, Michele. As mulheres ou os silêncios da história. Bauru: EDUSC, 2005.

PIMENTEL, Elaine. As marcas do patriarcado nas prisões femininas brasileiras. Disponível em: https:/ / periodicos. ufpel.edu.br/ojs2/index.php/revistadireito/article/view/11434/7219.

PRIORI, Mary Del, (org.). História das Mulheres no Brasil. 8. ed. São Paulo: Contexto.

SAFFIOTI, Heleieth Iara Bongiovani. A Mulher na Sociedade de Classes: mito e realidade. 3. ed. São Paulo: Expressão Popular, 2013.

SAFFIOTI, Heleieth. O poder do macho. São Paulo: Moderna, 1987.

SCOT'T, Joan. Gênero: uma categoria útil para análise histórica. In: HOLANDA, Heloisa Buarque de. (org.). Pensamento feminista: conceitos fundamentais. Rio de Janeiro: Bazar do Tempo, 2019.

SERBENA, Carlos A. Considerações sobre o inconsciente: Mito, símbolo e arquétipo na Psicologia analítica. Disponível em: http://pepsic.bvsalud.org/scielo.php?script=sci_arttext\&pid=S1809-68672010000100010http://pepsic.bvsalud.org/scielo.php?script=sci_arttext\&pid=S1809-68672010000100010.

WEK, Alek. Alek Wek: a refugiada africana que virou top model internacional. São Paulo: Panda Books, 2010. 
Para publicar na revista Brasileira de Políticas Públicas, acesse o endereço eletrônico www.rbpp.uniceub.br

Observe as normas de publicação, para facilitar e agilizar o trabalho de edição. 